\title{
Aspergillus prosthetic valve endocarditis
}

\author{
IAN S. PETHERAM and ROGER M. E. SEAL \\ Sully Hospital, University Hospital of Wales, Sully, Penarth, South Glamorgan CF6 2YA
}

\begin{abstract}
Petheram, I. S. and Seal, R. M. E. (1976). Thorax, 31, 380-390. Aspergillus prosthetic valve endocarditis. The clinical, laboratory, and histopathological features of seven cases of Aspergillus fumigatus prosthetic valve endocarditis are presented. The exact nature of the lesion, a combination of infective fungal endocarditis and thrombosis on the prosthetic valve, is discussed and the difficulties in clinical diagnosis are emphasized. Helpful indications were sudden unexplained heart failure with the appearance of new murmurs, and emboli to large or medium-sized systemic arteries. Fever and anaemia were inconstant, and in no case was blood culture or precipitin investigation helpful. Spore contamination of operating theatre air was the likely source of infection, and measures taken to overcome this and other predisposing factors are discussed. Since medical diagnosis is usually late and the few reported cures in this condition have included replacement of the prosthesis, early surgical intervention combined with antifungal chemotherapy is advised.
\end{abstract}

Infective endocarditis following cardiac surgery occurs in about $1 \%$ of cases (Block et al., 1970). Most of these infections are caused by bacteria but in recent years there have been more frequent reports of fungal infections on artificial heart valves and attention has been drawn to clinical, laboratory, and pathological differences in presentation between endocarditis caused by these agents and bacteria (Andriole et al., 1962; Kammer and Utz, 1974). The first case of Aspergillus prosthetic valve endocarditis was reported by Newman and Cordell in 1964 and they found only six published cases of endocarditis caused by this organism up to that date. Stimulated by the occurrence of this condition after mitral valve replacement in a 13year-old girl, Kammer and Utz found and reviewed 39 other cases of Aspergillus endocarditis, 24 of these patients having received prosthetic valves or homografts. The increase in the number of reported cases parallels the development of cardiac surgery and particularly the increased numbers of prosthetic valves implanted (Engelman et al., 1973).

This paper describes seven cases of Aspergillus prosthetic valve endocarditis, and the clinical, laboratory, and pathological findings are discussed and compared with previous reports.

\section{SUBJECTS}

Seven patients ( 4 women, 3 men) died from $A$ sper- gillus fumigatus prosthetic valve endocarditis after⿳亠二口犬 open-heart surgery for cardiac valve replacement $\stackrel{0}{\circ}$ in an 18-month period from 1968 to 1970 . During this time, at 206 open-heart operations, 180 pros- $\overrightarrow{\overrightarrow{0}}$ thetic cardiac valves were inserted. There were 3 136 single valve replacements, and 16 double and four triple valve replacements. Eighty-five of the? prostheses were aortic (all Starr Edwards ball valves), 87 were mitral prostheses (53 being Starr 응 Edwards ball valves, 33 Beall floating disc valves, $x$ and 1 Starr Edwards tilting disc valve), and eight were tricuspid prostheses (6 Starr Edwards ball. valves and 2 Beall floating disc valves).

The operations were performed by three cardiothoracic surgeons at the regional cardiothoracic음 centre for South Wales. Routine antibiotic pro- $\rightarrow$ phylaxis, usually ampicillin and cloxacillin, was started on the morning of operation and given six- N hourly until the eighth postoperative day. Further courses of antibiotics were prescribed as necessary 0 according to the clinical and bacteriological situ- $-\omega$ ation. No antifungal agents were given prophylactically. None of the patients reported had pre-o viously suffered bacterial endocarditis and none had received a course of antibiotics in the month? before surgery.

Oral anticoagulation was begun routinely on the $\frac{\vec{D}}{\stackrel{0}{0}}$ third postoperative day when drainage tubes had $\cong$ been removed, and the dosage was adjusted ac- $\mathbb{Q}$ cording to daily Thrombotest results. At that time 
corticosteroid prophylactic therapy was administered if the operative procedure or postoperative course was expected to be difficult or prolonged. The pump oxygenators used were either the Rygg bag oxygenator or the Kay Cross oxygenator.

Operative details in the seven cases are described in Table I. Full pathological details were available in all seven cases but clinical and laboratory information was available only in patients 3 to 7 although some information was later obtained about the first two patients who died in other hospitals. Clinical and laboratory details are shown in Table II and pathological findings in Table III.

\section{CASE HISTORIES}

CASE 1 Following mitral replacement a 53-yearold man had a low-grade intermittent fever for a few days, but he was well on discharge, and on review a month later in out-patients he remained well. Three and a half months after his operation he was admitted to another hospital as an emergency with severe cyanosis, left ventricular failure,

T A B L E I

\begin{tabular}{|c|c|c|c|c|c|c|c|}
\hline Patient & Sex & Age & Prosthetic Valve & $\begin{array}{l}\text { Perfusion } \\
\text { Time }\end{array}$ & \multicolumn{2}{|c|}{ Antibiotic Prophylaxis } & Corticosteroids \\
\hline 1 & $\mathbf{M}$ & 53 & Starr Edwards mitral steel ball valve with & $2 \mathrm{~h} 30 \mathrm{~min}$ & Ampicillin & 7 days & Hydrocortisone 7 days \\
\hline 2 & $\mathbf{F}$ & 43 & $\begin{array}{l}\text { Starr Edwards mitral steel ball valve with } \\
\text { Teflon coated struts (size M3) }\end{array}$ & $1 \mathrm{~h} 55 \mathrm{~min}$ & Ampicillin & 7 days & None \\
\hline 3 & $\mathbf{M}$ & 48 & Beall (large) mitral prosthesis & $1 \mathrm{~h} 50 \mathrm{~min}$ & Tetracycline & 7 days & None \\
\hline 4 & $\mathbf{F}$ & 43 & Starr Edwards mitral steel ball valve with & $1 \mathrm{~h} 48 \mathrm{~min}$ & Ampicillin & 10 days & None \\
\hline 5 & $\mathbf{F}$ & 39 & Beall (small) mitral prosthesis & $1 \mathrm{~h} 55 \mathrm{~min}$ & Ampicillin & 7 days & None \\
\hline 6 & $\mathbf{M}$ & 26 & $\begin{array}{l}\text { Starr Edwards aortic ball valve (size A9) and } \\
\text { Starr Edwards tilting disc mitral prosthesis }\end{array}$ & $3 \mathrm{~h} 48 \mathrm{~min}$ & Ampicillin & 7 days & Hydrocortisone 7 days \\
\hline 7 & $\mathbf{F}$ & 32 & $\begin{array}{l}\text { with Teflon coated struts (size M3) } \\
\text { Starr Edwards mitral steel ball valve with } \\
\text { Teflon coated struts (size M3) }\end{array}$ & $2 \mathrm{~h} 19 \mathrm{~min}$ & $\begin{array}{l}\text { Cephaloridine } \\
\text { Ampicillin } \\
\text { Cloxacillin } \\
\text { Tetracycline }\end{array}$ & 7 days & None \\
\hline
\end{tabular}

T A B L E I I

\begin{tabular}{|c|c|c|c|c|c|}
\hline Patient & Postoperative course & $\begin{array}{l}\text { Onset of } \\
\text { Illness }\end{array}$ & Died & Clinical Features & Investigations \\
\hline 1 & $\begin{array}{l}\text { Low-grade fever but afebrile at } \\
\text { discharge on day } 31 \text { post-op. Well in } \\
\text { outpatients one month later }\end{array}$ & Day 103 & Day 105 & $\begin{array}{l}\text { Cyanosis, left ventricular failure, } \\
\text { painful splenomegaly. No } \\
\text { temperature }\end{array}$ & Not available \\
\hline 2 & Discharged well on day 31 & Day 41 & Day 44 & $\begin{array}{l}\text { Malaise, haematuria. No } \\
\text { splenomegaly. No further details }\end{array}$ & Not available \\
\hline 3 & $\begin{array}{l}\text { Low-grade intermittent fever, } \\
\text { discharged otherwise well on day } 24\end{array}$ & Day 77 & Day 77 & $\begin{array}{l}\text { known } \\
\text { Cyanosis, dyspnoea, cardiac failure. } \\
\text { Low-grade intermittent } \\
\text { temperature. No splenomegaly; } \\
\text { apical pansystolic murmur and } \\
\text { diastolic murmur. Hypotension, no }\end{array}$ & $\begin{array}{l}\text { Haemoglobin } 13 \cdot 9 \mathrm{~g} / \mathrm{dl} \text {. } \\
\text { White cell count } 18000 \\
76 \% \text { polymorphs. Blood } \\
\text { cultures negative } \times 5\end{array}$ \\
\hline 4 & $\begin{array}{l}\text { Transient fever but afebrile at } \\
\text { discharge on day } 43 \text {. Noted } \\
\text { pansystolic murmur and cardiac } \\
\text { failure on day } 64\end{array}$ & Day 64 & Day 143 & $\begin{array}{l}\text { Severe cardiac failure with } \\
\text { pansystolic murmur, lower } \\
\text { abdominal pain, hemiplegia. } \\
\text { Low-grade intermittent fever. No } \\
\text { splenomegaly. Amphotericin } \\
\text { intravenously for last four days }\end{array}$ & $\begin{array}{l}\text { Haemoglobin } 10 \cdot 5 \mathrm{~g} / \mathrm{dl} \text {. } \\
\text { White cell count } 23000 \\
95 \% \text { polymorphs. Blood } \\
\text { cultures negative. A. } \\
\text { fumigatus precipitins } \\
\text { absent }\end{array}$ \\
\hline 5 & Discharged well day 34 & Day 67 & Day 68 & $\begin{array}{l}\text { Severe cardiac failure with apical } \\
\text { pansystolic murmur, hypotension, } \\
\text { no splenomegaly, lesion on right } \\
\text { conjunctiva. No fever }\end{array}$ & $\begin{array}{l}\text { Haemoglobin } 13 \cdot 1 \mathrm{~g} / \mathrm{dl} \text {. } \\
\text { Blood cultures negative. } \\
\text { White cell count } 26000\end{array}$ \\
\hline 6 & $\begin{array}{l}\text { Afebrile until day } 21 \text {. Apical } \\
\text { systolic murmur and diastolic } \\
\text { murmur at left sternal edge on } \\
\text { day } 20\end{array}$ & Day 12 & Day 27 & $\begin{array}{l}\text { High swinging fever. Anaemia, } \\
\text { haemolysis, jaundice, cardiac } \\
\text { failure, hypotension, left abdominal } \\
\text { pain. No splenomegaly }\end{array}$ & $\begin{array}{l}\text { Haemoglobin down to } \\
8 \cdot 4 \mathrm{~g} / \mathrm{dl} \text {. White cell count } \\
8900 \text {. Blood cultures } \\
\text { negative }\end{array}$ \\
\hline 7 & $\begin{array}{l}\text { Intermittent fever but normal by } \\
\text { discharge on day } 33\end{array}$ & Day 57 & Day 62 & $\begin{array}{l}\text { Haemoptysis, cyanosis, cardiac } \\
\text { failure, pansystolic murmur and } \\
\text { diastolic murmur at apex. } \\
\text { Splenomegaly, no fever. No clinical } \\
\text { emboli. Hypotension }\end{array}$ & $\begin{array}{l}\text { Haemoglobin } 12 \cdot 3 \mathrm{~g} / \mathrm{dl} \text {. } \\
\text { White cell count } 11800 \\
\text { Blood cultures negative. } \\
\text { A. fumigatus precipitins } \\
\text { absent }\end{array}$ \\
\hline
\end{tabular}


T A B L E I I I

\begin{tabular}{|c|c|c|c|}
\hline Patient & Findings at Valve & Histology/Culture of Vegetations & Embolism \\
\hline 1 & $\begin{array}{l}\text { Severe obstruction. Struts partly covered } \\
\text { restricting ball movement. Neither complete } \\
\text { opening nor closing, also regurgitant }\end{array}$ & $\begin{array}{l}\text { Heavy pure growth of Aspergillus. Slight } \\
\text { inflammatory reaction }\end{array}$ & Spleen-'bland' \\
\hline 2 & $\begin{array}{l}\text { Failure of valve seating with regurgitation. } \\
\text { No detachment }\end{array}$ & $\begin{array}{l}\text { Pure growth of Aspergillus with slight } \\
\text { inflammatory reaction }\end{array}$ & $\begin{array}{l}\text { Possibly cerebellum-uncertain, } \\
\text { not infective }\end{array}$ \\
\hline 3 & $\begin{array}{l}\text { Severe obstruction with detachment, disc } \\
\text { seating failure, and valvar regurgitation }\end{array}$ & $\begin{array}{l}\text { Vegetations of pure } A \text {. fumigatus with } \\
\text { moderate inflammatory response }\end{array}$ & None \\
\hline 4 & $\begin{array}{l}\text { Valve moderately obstructed causing } \\
\text { regurgitation with detachment }\end{array}$ & $\begin{array}{l}\text { Vegetations of pure } A \text {. fumigatus. Slight } \\
\text { inflammatory response }\end{array}$ & $\left.\begin{array}{l}\text { Spleen } \\
\text { Kidney } \\
\text { L. cerebral }\end{array}\right\}$ 'bland' \\
\hline 5 & $\begin{array}{l}\text { Severe valve obstruction. No detachment, } \\
\text { no regurgitation }\end{array}$ & $\begin{array}{l}\text { Vegetations of pure } A . \text { fumigatus. Slight } \\
\text { inflammatory response }\end{array}$ & $\begin{array}{l}\text { None. Right eye lesion not } \\
\text { examined }\end{array}$ \\
\hline 6 & $\begin{array}{l}\text { Severe obstruction of mitral valve by } \\
\text { vegetations. Slight incompetence of aorta but } \\
\text { not caused by fungus }\end{array}$ & $\begin{array}{l}\text { Vegetations of pure } A \text {. fumigatus. Moderate } \\
\text { inflammatory response }\end{array}$ & $\left.\begin{array}{l}\text { Both kidneys } \\
\text { Spleen }\end{array}\right\}$ 'bland' \\
\hline 7 & $\begin{array}{l}\text { Valve severely obstructed. No detachment, } \\
\text { no regurgitation }\end{array}$ & $\begin{array}{l}\text { Vegetations of pure } A \text {. fumigatus. Slight } \\
\text { inflammatory reaction }\end{array}$ & None \\
\hline
\end{tabular}

and tender splenomegaly but no fever. Diuretics were ineffective and he died two days later.

Necropsy The orifice of the mitral valve was obstructed on its atrial aspect by pale friable vegetations (Fig. 1). On the ventricular aspect the struts of the prosthesis were partly covered at the base, and the movements of the ball in the cage were restricted by the vegetation so that it could neither open nor close completely (Fig. 2). Histology of the vegetations revealed a mass of septate branch-

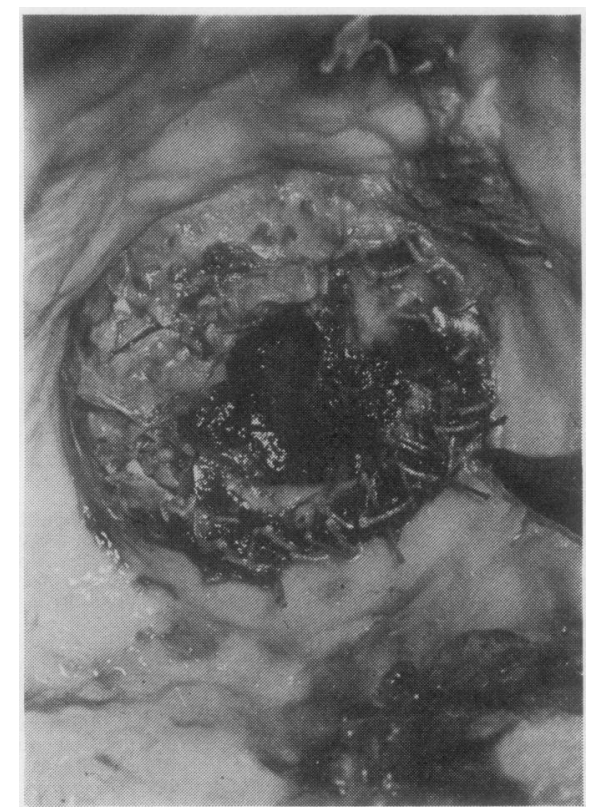

FIG. 1. Case 1. Starr Edwards valve from atrial aspect showing pale friable vegetations producing an eccentric stenosed lumen.

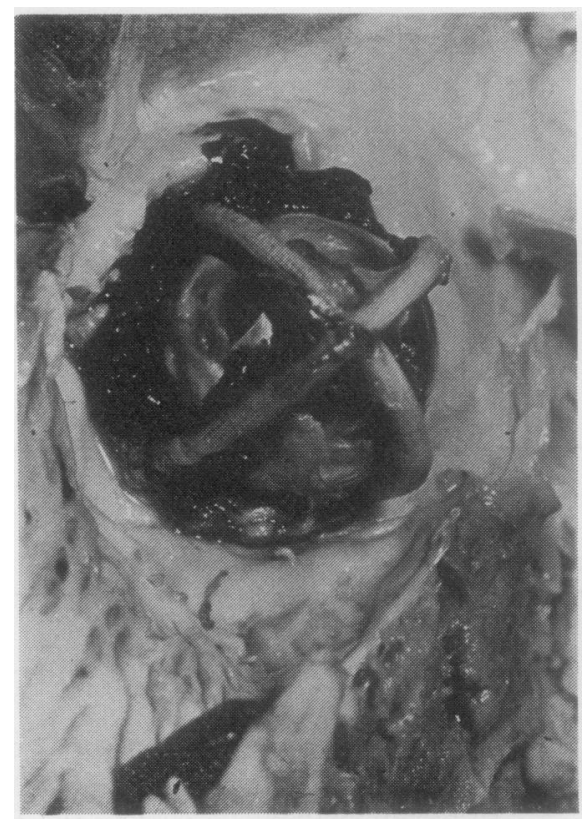

FIG. 2. Case 1. Starr Edwards valve from ventri cular aspect showing some pale grey vegetations, later ally and superiorly. There is also more recent mixed thrombus, probably agonal.

ing hyphae typical of Aspergillus (later confirme by culture) with a slight surrounding inflammatorye response. Examination of the spleen revealed a re $\Phi$ cent infarct by a bland fungal 'thrombus'. There was no evidence of embolism to any other organ CASE 2 A 43-year-old-woman had a mitral valv@ replacement with an unremarkable postoperative course, and she was discharged on the 31st dayp 
Ten days later she developed haematuria and was admitted to another hospital. Her prothrombin time was excessively prolonged but although this returned to normal with vitamin $\mathrm{K}$ therapy three days after admission she went into coma and died. No information was obtained about her cardiovascular state.

Necropsy The atrial surface of the mitral valve was covered with a large number of soft vegetations around the inner and outer margins of the prosthetic ring. On its undersurface the vegetations surrounded the struts superiorly and the ring, preventing efficient seating of the ball (Fig. 3 ). Histology of these vegetations revealed branching septate hyphae typical of Aspergillus with only slight inflammatory response (Fig. 4). Culture of the vegetations grew $A$. fumigatus. There were old and recent infarcts in the kidneys and a large haemorrhage into the left lobe of the cerebellum but no fungi were seen at this site.

CASE 3 After insertion of a Beall mitral prosthesis a 48-year-old man had a continuous lowgrade intermittent fever but was otherwise well. He was discharged on the 24th postoperative day

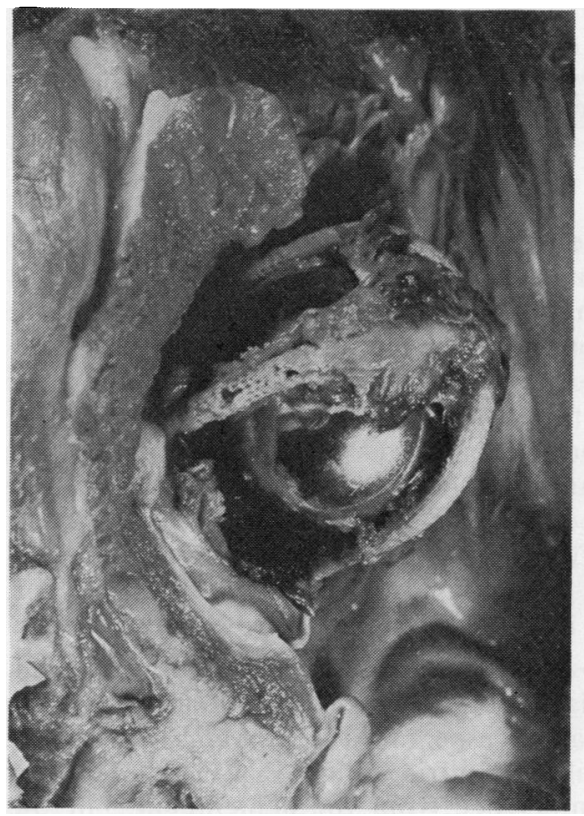

FIG. 3. Case 2. Starr Edwards valve from below showing vegetations, superiorly, on ring preventing closure and lesser vegetations, inferiorly, limiting full opening.

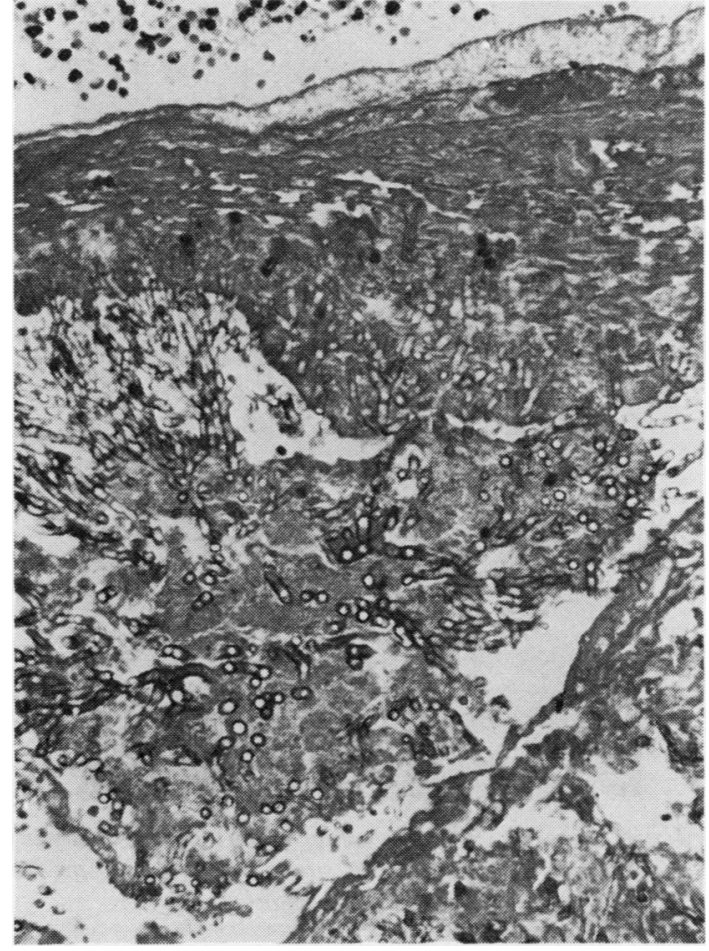

FIG. 4. Case 2. Showing branching septate mycelium in amorphous 'thrombotic' material but with only minimal cellular inflammatory exudate (Haematoxylin and eosin $\times 116$ ).

and on review in the outpatient department five weeks later was well with no dyspnoea, no signs of cardiac failure, and no abnormality in the prosthetic valve sounds. In the eleventh week postoperatively he was admitted as an emergency with severe dyspnoea, cyanosis, hypotension, and left ventricular failure. Apical systolic and diastolic murmurs were heard. The haemoglobin was 13.9 $\mathrm{g} / \mathrm{dl}$, and the white cell count $18.0 \times 10^{\circ}$ with $76^{\circ} \%$ polymorphonuclear leucocytes. He had a lowgrade intermittent pyrexia. He became unconscious and despite assisted ventilation died on the day of admission. Blood cultures proved negative for bacteria and fungi.

Necropsy The mitral valve orifice was occluded on the atrial aspect by pale 'thrombus'. Vegetations were found on the ventricular aspect of the valve, around the edge, and growing over and under the medial struts. The other strut was completely uninvolved (Fig. 5). These vegetations on the under surface interfered with disc seating with 


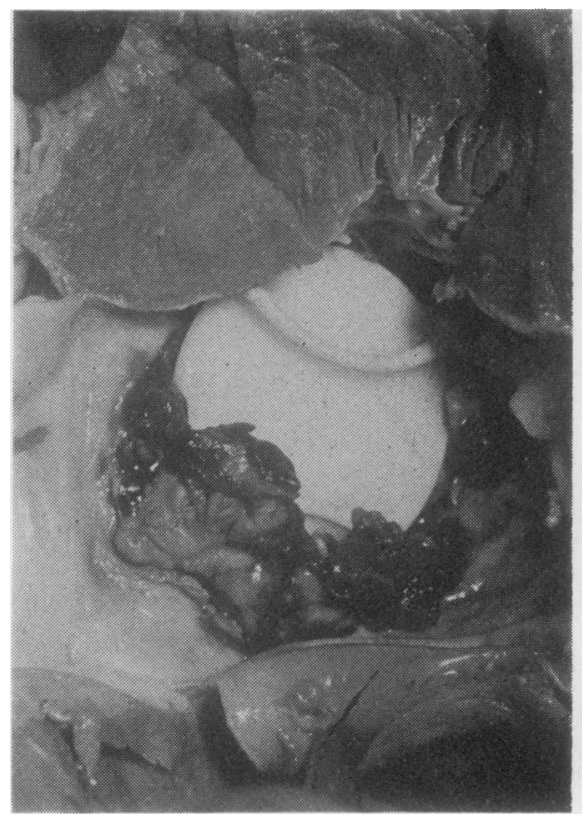

FIG. 5. Case 3. Beall valve from below showing vegetations, inferiorly and superiorly to the medial strut, clearly impeding disc movement.

consequent incompetence. In addition there was early detachment of the valve involving about a half of its circumference. There was no evidence of infarction in any organ. A wet preparation of the thrombotic material clearly showed numerous branching septate hyphae suggesting Aspergillus and Mucor, and the fungus showed the cultural characteristics of $A$. fumigatus. Histology of the vegetations revealed a moderate surrounding inflammatory response (Fig. 6).

CASE 4 After mitral valve replacement in a 43year-old woman the postoperative course was complicated by a transient fever lasting four days, but she then remained well until discharge on the 43rd day. One month later she was found to be in heart failure with a pansystolic murmur at the apex but there was no fever. Diuretics and digitalis were prescribed. She was readmitted as an emergency on the 100th postoperative day with a three-week history of headache, nausea, and intermittent fever with rigors. She had received three different antibiotics without effect. Examination revealed mitral regurgitation, hepatomegaly, photophobia, and neck stiffness. The haemoglobin was $10.5 \mathrm{~g} / \mathrm{dl}$, sedimentation rate $100 \mathrm{~mm}$ in the first hour, and

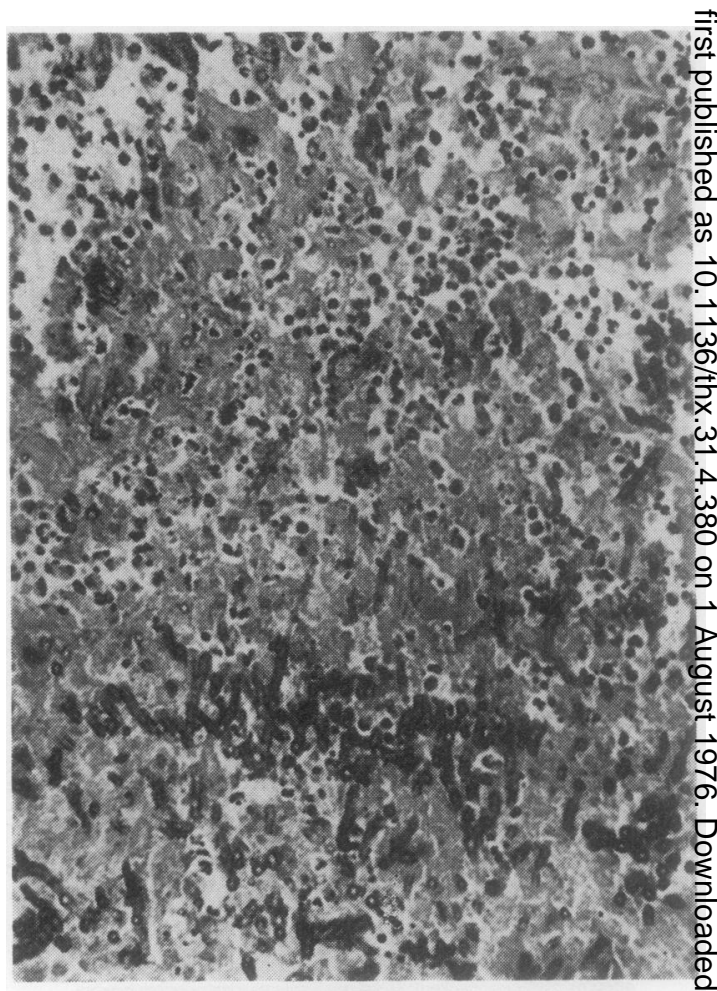

FIG. 6. Case 3. Branching septate mycelium i 'thrombotic' material but with numerous polymorpho nuclear leucocytes $(H$ and $E \times 116)$.

white cell count $23.0 \times 10^{\circ}, 88 \%$ of which wer民్ polymorphs. A lumbar puncture produced a unie formly bloodstained fluid. A diagnosis of infective endorcarditis with mitral valve detachment was made. Blood cultures were negative for bacteriæ and fungi and no precipitins to $A$. fumigatus were found in the serum. Her condition did not respon $\Phi$ to parenteral broad-spectrum antibiotics, and intra? venous amphotericin B was added. She deteriora ted further and developed left hypochondrial pair with radiation to the tip of the left shoulder. ShE died in coma on the 143rd postoperative day. N

Necropsy The mitral valve was detached an partially occluded by pale, friable vegetations oq the atrial aspect, leaving only a one centimetrథ circular eccentric orifice (Fig. 7). There was minor incompetence from the detachment, but the bap was capable of proper seating. A recent wedge shaped infarct was found in the spleen and a large infarct in the left kidney, and the left middle ceree bral artery was occluded by brown 'thrombus 


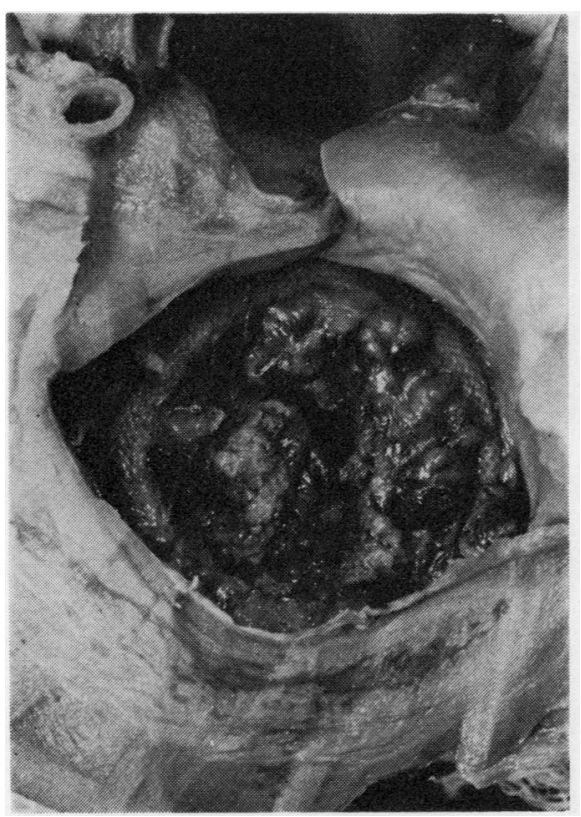

FIG. 7. Case 4. Starr Edwards valve from above almost totally occluded by vegetations producing obstruction to the orifice. The small crescentic orifice where detachment has occurred can be seen.

near its origin. Histology of the vegetations revealed the typical septate branching hyphae of $A$. fumigatus, later confirmed by culture. There was only a slight inflammatory response; in places the appearance was that of almost pure fungal growth with abortive attempts at sporing head formation (Fig. 8). Histology of the kidney showed a medium-sized artery occluded by thrombus firmly attached to the wall. The appearances were of a bland thrombus, and a Gomori stain revealed small fragments of fungal hyphae (Fig. 9).

CASE 5 A 39-year-old woman made an uncomplicated recovery and was discharged on the 24th day after mitral valve replacement, but she was readmitted six weeks later with a three-week history of blindness in the right eye, dyspnoea, and vomiting. Examination revealed a severely ill patient in left ventricular failure with a pansystolic murmur at the apex, and a lesion was noted on the conjunctiva of the right eye. She was afebrile but soon became hypotensive and unconscious, death occurring the day after admission. Her haemoglobin was $13.1 \mathrm{~g} / \mathrm{dl}$ and white count $26.0 \times 10^{\circ}$; blood cultures were sterile for bacteria and fungi.
Necropsy The prosthetic valve was well seated but the orifice was almost completely occluded by firm, pale 'thrombus' (Fig. 10). No recent infarcts were found in any organ. Histology and, later, culture of the vegetations showed a pure growth of $\boldsymbol{A}$. fumigatus with a slight inflammatory response. The conjunctival lesion was not examined.

CASE 6 After a double valve replacement a 26year-old man was afebrile until the 12th postoperative day when he developed a high swinging fever and consolidation at the right lung base. A pansystolic murmur was noted at the apex and an early diastolic murmur at the left sternal edge. The haemoglobin fell to $8.4 \mathrm{~g} / \mathrm{dl}$, he became jaundiced, and haemolysis was demonstrated. His condition slowly deteriorated with hypotension and left-sided abdominal pain. Despite diuretics, blood transfusion, and intravenous hydrocortisone he became unconscious and died on the 27 th postoperative day. The highest white blood count was $8.9 \times 10^{\circ}$.

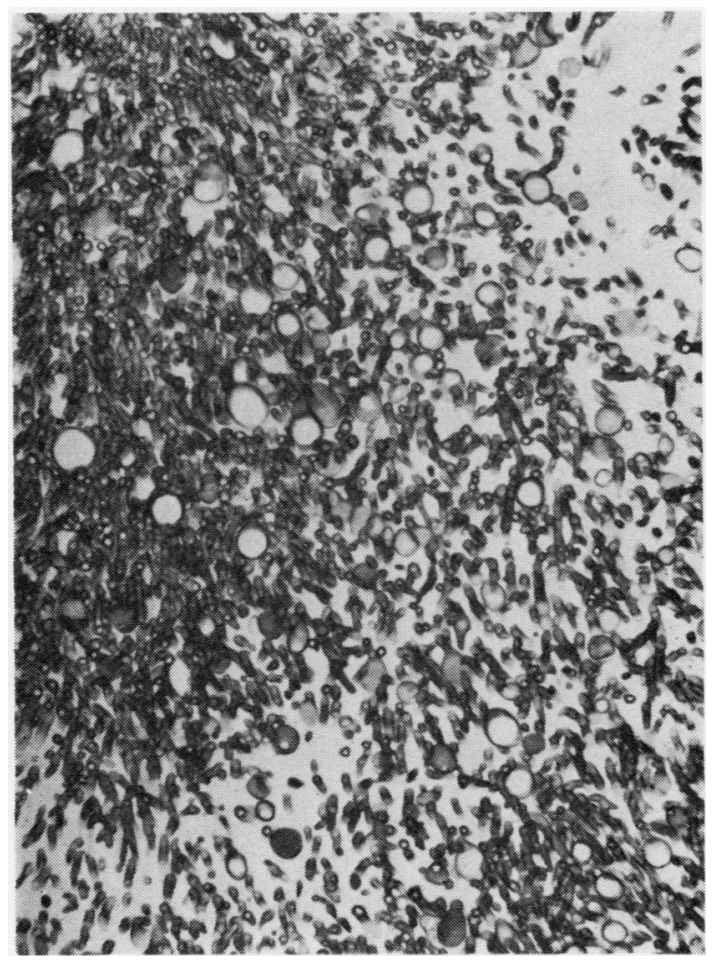

FIG. 8. Case 4. An area of almost pure growth of fungus with numerous vesicles or receptacles but without any sterigmata or conidiospores (Gomori $\times 78$ ). 
Necropsy Both aortic and mitral prostheses were well seated but the mitral valve was obstructed by pale, firm vegetations attached to the Teflon ring. Wet preparations of this material revealed the branching hyphae typical of $A$. fumigatus which was confirmed by culture. There was a little pale 'thrombotic' material on the Teflon struts of the aortic valve but this seemed to cause no mechanical embarrassment. There were recent infarcts in the kidneys and the spleen.

CASE 7 A 32-year-old woman had three isolated spikes of pyrexia after mitral valve replacement but was discharged, having been afebrile for a fortnight, on the 31 st postoperative day. She was readmitted eight weeks after operation because of haemoptysis. Examination revealed left ventricular failure with a pansystolic murmur at the apex. The haemoglobin was $12.3 \mathrm{~g} / \mathrm{dl}$ and the white count $11.8 \times 10^{\circ}$. Although she remained

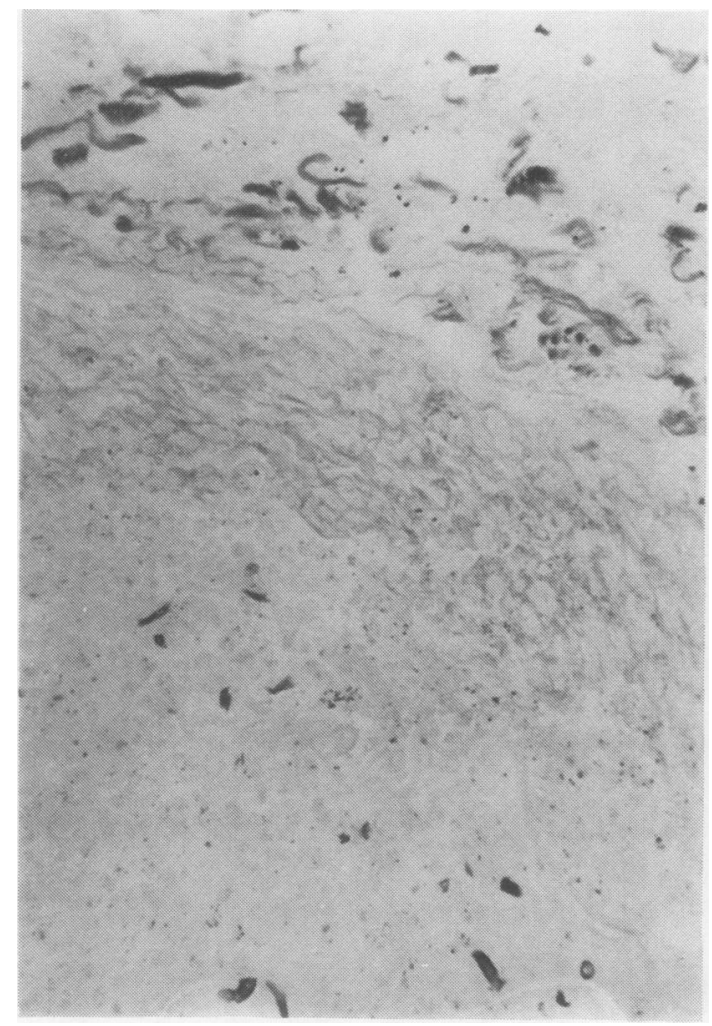

FIG. 9. Case 4. A section across a thrombosed renal artery with small fragments of mycelium in the bland thrombus.

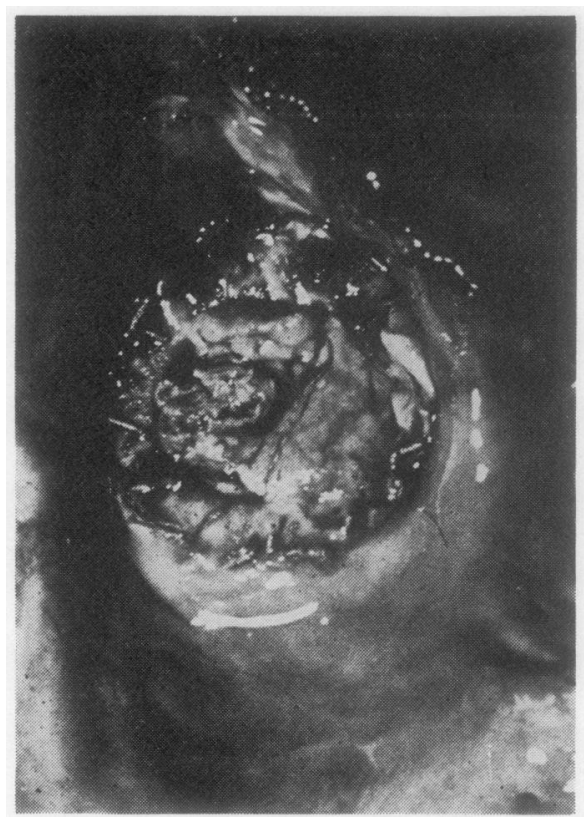

FIG. 10. Case 5. Beall valve from atrial aspect wit its orifice almost completely occluded by vegetation which were firm peripherally and more friable cern trally.

afebrile, over the next two days she became cyas nosed and hypotensive. Blood cultures were nega tive for bacteria and fungi and the serum was negative for $A$. fumigatus precipitins. She becam $\overrightarrow{5}$ unconscious and died on the 62 nd postoperative day.

Necropsy The prosthetic valve was well seate with no incompetence but the lumen was cone siderably narrowed by pale, firm, thrombotie vegetations, the orifice being less than a square centimetre in area. Similar vegetations were seen on the under surface around the struts. Histolog revealed a profuse growth of pale branching sepN tate hyphae typical of $A$. fumigatus confirmed by culture. There was an old infarct of the left kidnes but no evidence of recent embolism to any organ

\section{DISCUSSION}

The basic lesion found in Aspergillus prosthetice্ valve endocarditis is a mass of greyish-brown ${ }^{\text {? }}$ thrombotic material obstructing the orifice or im $=0$ pairing the movement of the ball or disc withir its cage. Since the histopathological appearances in cases 3 and 6 revealed a moderate neutrophiB response, while the inflammatory reaction to the 
presence of fungus in the other patients was minimal it is interesting to speculate whether the lesion represents primarily a thrombus in which Aspergillus grows or whether the condition can be regarded as a true infective endocarditis. Ineffective anticoagulation might promote thrombosis on the prosthesis on which organisms settle or the inflammatory reaction caused by the infection could stimulate thrombus formation. At the sites of embolic complications no myotic aneurysms were produced. The infarcts were bland and we were impressed by the poor local inflammatory response in some patients with this condition. In the present series the patients were anticoagulated with phenindione on the third postoperative day and therapeutic levels $(10-20 \%)$ were achieved in each case within 24 hours. There was nothing in these patients to suggest unusual management of anticoagulation, and Aspergillus endocarditis has been reported affecting biological tissue valves which do not require anticoagulation (Clinico-pathological conference, 1969; Public Health Laboratory Service, 1970). Although examples of Aspergillus infection on 'normal' endocardium have occurred in patients debilitated by other diseases (cases 1-9, Kammer and Utz, 1974), Aspergillus endocarditis is almost entirely a problem after cardiac surgery. The evidence suggests to us that the likely mechanism is that fungal spores are deposited on a valve and that the minimal inevitable thrombus, which forms perhaps during the 48 hours between reversal of heparin used in cardiopulmonary bypass and adequate oral anticoagulation, acts as a nidus and a medium for further growth. Although all valves infected in this series were in the mitral position, only in case 5 was a smaller than average size used. Stasis around the prosthesis promoting thrombosis would not, therefore, appear likely.

The diagnosis of this condition presented great difficulty and except in case 6 there was little in the early postoperative period suggesting the eventual diagnosis. The clinical manifestations were a combination of features of infective endocarditis and mechanical dysfunction caused by thrombus on the prostheses. Several features suggest that this condition is different from the commoner bacterial prosthetic endocarditis. In all but one patient in this series the onset of clinical illness was delayed, six of the patients being discharged well from hospital yet it is of interest to note the rapidly progressive terminal illness in cases $1,2,3$, 5 , and 7. The onset of illness after operation in our patients ranged from the 12th to the 102nd postoperative day although it has presented as early as the first day (Chaudhuri, 1970; Newman and Cordell, 1964) or as late as 23 months after surgery (Hairston and Lee, 1970). In contrast, Dismukes et al. (1973) found that bacterial prosthetic endocarditis attributable to the septic complications of surgery or the immediate postoperative period presented within 60 days of operation. This relatively late presentation of Aspergillus endocarditis may mean that this diagnosis is overlooked, particularly if the patient is admitted to a different hospital.

Although fever was present in all 12 cases of bacterial prosthetic endocarditis reported by Block et al. (1970), in 21 cases of Candida endocarditis described by Andriole et al. (1962), and in 33 out of 35 cases of Aspergillus endocarditis reported by Kammer and Utz (1974), we would emphasize that this condition may be present in an afebrile patient. The embolic manifestations also differ from bacterial endocarditis, the characteristic feature in fungal endocarditis being the involvement of large or medium-sized arteries to major organs or limbs. In three patients in this series (1, 4 , and 6) there were good clinical grounds for suspecting emboli to spleen, brain, and either kidney or spleen respectively. These lesions were confirmed at necropsy with obstruction of large or medium-sized arteries. Other reports confirm that common sites for emboli in fungal endocarditis are the major arteries to the brain, kidneys, spleen, and limbs (Andriole et al., 1962; Kammer and Utz, 1974).

All our patients developed cardiac failure as is commonly found with bacterial endocarditis on prosthetic valves (Shafer and Hall, 1970). Prosthetic valve incompetence may result from detachment due to technically inadequate sutures, softening of paravalvar tissues by infection, or failure of ball or disc seating due to thrombus or vegetations. The appearance of new murmurs was noted in all our patients and careful auscultation for mitral diastolic murmurs or alterations in opening valve clicks can be valuable signs of obstruction to prostheses. In five cases a pansystolic murmur was heard at the apex, and two patients also had apical diastolic murmurs (cases 3 and 7). Both were hypotensive and in pulmonary oedema and were found to have severe obstruction of the mitral prosthetic ring on the atrial aspect. Two other patients (cases 5 and 6 ) were hypotensive and in pulmonary oedema and their mitral prostheses were obstructed although diastolic mitral murmurs were not heard. Valve detachment was found in two patients and the fungal endocarditis was considered the cause. Fourteen out of 24 cases of Aspergillus prosthetic endocarditis reviewed by 
Kammer and Utz (1974) developed murmurs, and in one the disappearance of the opening click of a Starr Edwards aortic prosthesis was noted.

We did not find haematological investigations helpful in diagnosing this condition. The haemoglobin was normal in three out of five patients and the white cell count raised in four due to increased numbers of neutrophils. One patient (case 6) was considered to have mechanical destruction of erythrocytes due to a leaking aortic prosthesis. It was not thought that fungal infection had caused detachment of this valve. Our haematological findings concur with those of Kammer and Utz (1974) who found the white count commonly raised, but anaemia was absent in twothirds of their series.

A major difficulty in making the diagnosis in life was the failure to grow the organism even on Sabouraud medium and this has been the experience of other authors. Only three out of 37 patients reviewed by Kammer and Utz (1974) had positive blood cultures and cultures were even negative in a patient with profuse purpura and other evidence of embolism (Harford, 1974). This contrasts strongly with the ease with which the pathogens can be cultured in Candida endocarditis (Andriole et al., 1962). Possible reasons for the difficulty in culturing Aspergillus species may be:

(1) Growth of Aspergillus is vegetative and sterile and the organism does not sporulate in blood. Fungaemia is probably not a true infective fungaemia but the breaking off of large fungal masses which, unlike bacterial endocarditis (Werner et al., 1967), is probably intermittent. Even blood taken within six hours of death from the left atrium near an infected mitral prosthesis was negative on culture (personal observation).

(2) The spores are readily ingested by phagocytes but may not be completely killed (Mullins, 1975). Although the organism grows adequately on most culture media at $37^{\circ} \mathrm{C}$ perhaps the initial intracellular existence of the organism slows the growth of the fungus, causing a balance between infection and host response which may explain the long symptom-free interval noted in this and other series and the negative blood cultures.

(3) Blood culture sampling is usually from veins but since $95 \%$ of Aspergillus valve infections are in the left heart the embolic fungal mass may be too large to pass through the systemic capillary circulation. However, arterial samples were obtained in two of the patients reviewed by Kammer and Utz (1974) and in one of our patients but culture of these samples failed to grow fungi.

It was unfortunate that sera of two patients (cases 4 and 7) examined were negative for Asper $\overrightarrow{\vec{F}}$ gillus precipitins and the presence of fungus did not provoke an antibody response. It is interesting to consider why the growth of Aspergillus in lung cavity produces precipitating antibodies inf $99 \%$ of cases but these are absent in the presencen of florid growth on an artificial valve. There seems to be no obvious explanation. It would seemP reasonable to think that base-line sera before and $\overrightarrow{\mathrm{t}}$ after operation would help in evaluating patientso suspected of having fungal prosthetic endocarditis However, it must be appreciated that antibodies to Candida can develop in the absence of infection of the endocardium (Murray et al., 1969).

Necropsy diagnosis of this condition shouldo offer no difficulty as examination of a suspectedp vegetation by a wet smear reveals the branching septate hyphae of what could be either Asper $\rightarrow$ gillus or Mucor, and culture of the material yieldso fungal colonies. Their characteristic appearances? together with the nature of the sporing head contained will enable the species of Aspergillus to be established.

SOURCE OF INFECTION The possible routes of in fection included contamination of theatre air, oro the blood in the oxygenator or the introduction of infection in the postoperative period through in 0 travenous lines. We concur with Kammer and $\overrightarrow{0}$ Utz (1974) and Gage et al. (1974) that deposition? of fungal spores at the time of operation is the most likely explanation. After identifying the first three patients in this outbreak a carefulf search was made of the operating theatre en 음 vironment for a possible source of entry of thex spores. Green dust containing small natural and? man-made fibres from theatre swabs and surgeons gowns were collected from the ventilation system in quantities sufficient to fill a large sweet jar. Culture of this dust revealed a profuse growth of $A$. fumigatus. The ventilation system was throughly cleaned and the theatres were repainted, but three months after surgery was restarted fur $N$ ther cases occurred. The existing ventilation ducts were sealed off and a self-contained Octatent with Plenum positive pressure ventilation was installed. $\mathcal{E}$ Sampling of theatre and equipment for $A$. fumi gatus spores demonstrated that these measureso were successful in reducing the spore counts al- $-\infty$ most to zero although sampling in other rooms in ${ }^{-}$ the theatre suite continued to show spore counts 0 in lower concentrations compared with outside $\frac{\vec{\Phi}}{\mathbb{Q}}$ air but having the same day-to-day fluctuations. $\stackrel{?}{9}$ Occasionally the concentrations in the theatre rose quite independently of the counts outside, and 
some of these rises seemed associated with the changing of the filter of the ventilation system. It was demonstrated that over a period of one month $7.5 \times 10^{6} \mathrm{~A}$. fumigatus spores were collected in the filter and that a cloud of spores was released into the theatre suite when the filter was changed (Mullins, 1974). It is, therefore, concluded that the majority of our patients underwent surgery in a particularly heavily contaminated fungal environment but that the last case occurred when the Aspergillus content of the theatre air was that which may be found in any operating theatre where constant attention to the filters is not rigorously maintained. Gage et al. (1974) described large numbers of colonies of Aspergillus grown from moss and pigeon excreta near the ventilation inlet to their operating area and concluded that this was the route of infection in their cases.

Aspergilli are ubiquitous hardy organisms that reproduce vegetatively and have a low pathogenicity for healthy man. They spread in spore form and can be recovered in or out of doors, more commonly in winter than in summer (related to humidity), and are particularly concentrated in or near decaying matter. In culture at room or body temperature and in infected tissue they assume the mycelial form by rapid growth. The colonies have septate mycelia with knob-like terminations (vesicles) which develop into conidiophores. The organism does not produce spores without an air interface so that the spores are not found in the bloodstream although vesicle formation at the ends of some stalks suggests that the spore-producing process may begin even if it cannot be completed (Mullins, 1975). It is an opportunist organism which can proliferate in an apparently immunologically normal host in a preformed lung cavity or in a haemothorax (Hiddleston, Rosser, and Seal, 1954). Systemic infection occurs when the immune response is altered by disease, cytotoxic drugs, or corticosteroids or when broadspectrum antibiotics eliminate competitive body flora.

In cardiac valve replacement there is the abnormal situation of a foreign body in the circulation upon which the fungal mycelium can proliferate. Although all our patients received broad-spectrum antibiotic prophylaxis there was no difference in the prescribing of these drugs in the infected and the non-infected group. While corticosteroids are now commonly used prophylactically, at the time of this outbreak they were administered in selected cases only, and five of our patients did not receive them. Engelman et al. (1973) sugges:ed that duration of operation was a relevant predisposing factor since it may affect the size of the infecting dose. Similarly, Lee et al. (1961) showed that bactericidal properties of blood may be altered by protein denaturation at the oxygenation membrane interface of the heart-lung apparatus and could be a further reason why prolonged operations would predispose to infection.

We find little support for these suggestions since the mean perfusion time for single mitral valve replacements in our series was 2 hours 3 minutes compared with a mean perfusion time of 2 hours 4 minutes for all other single mitral replacements although the mean time for double valve replacements was 2 hours 46 minutes compared with 3 hours 48 minutes in patient 6 . Infective pathogens have been recovered from the heart-lung apparatus itself (Yeh et al., 1967) although this was not the experience of Hairston and Lce (1970) nor in the present series.

Infection on prosthetic valves is notoriously difficult to cure even when the organisms are sensitive to chemotherapeutic agents and valve replacement plus drug therapy has been necessary to achieve cure in most of the reported cases. Hairston and Lee (1970) reported cure of Aspergillus prosthetic endocarditis on a mitral valve, which had become detached, by valve replacement but no antifungal agent was given, the diagnosis being made by culture of the removed valve. Amphotericin B alone has been given to several patients (Caplan et al., 1968; Hairston and Lee, 1970) but without success although cure with antifungal therapy alone in Candida endocarditis has been achieved in this department (Boyce, 1975) and has been reported in Candida endocarditis occurring both before and after surgery (Andriole et al., 1962; Conway et al., 1968). A further recent report of cure of Aspergillus ustus endocarditis with amphotericin B, 5 fluocytosine, and surgical removal of an aortic Starr Edwards ball valve (Carriza et al., 1974) emphasizes the need for a combined medical and early surgical approach in the management of this condition.

We thank our surgical colleagues Mr. D. M. E. Thomas, Mr. H. R. S. Harley, and Mr. T. H. L. Rosser for permission to report these cases; Dr. G. S. Andrews, consultant pathologist, Royal Gwent Hospital, Newport, for permission to report the necropsy findings on cases 1 and 2; Dr. J. Mullins and Dr. L. G. Davies for much helpful advice; and Mr. B. Boothby, Department of Medical Illustration, Llandough Hospital, for the photographs. 


\section{REFERENCES}

Andriole, V. T., Kravetz, H. M., Roberts, W. C., and Utz, J. D. (1962). Candida endocarditis, clinical and pathologic studies. American Journal of Medicine, 32, 251.

Block, P. C., DeSanctis, R. W., Weinberg, A. N., and Austen, W. G. (1970). Prosthetic valve endocarditis. Journal of Thoracic and Cardiovascular Surgery, 60, 540.

Boyce, J. M. H. (1975). A case of prosthetic valve endocarditis caused by Corynebacterium hofmanni and Candida albicans. British Heart Journal, 37, 1195.

Caplan, H. I., Frisch, E., Houghton, J. D., Climo, M. S., and Natsios, G. A. (1968). A spergillus fumigatus endocarditis; report of a case diagnosed during life. Annals of Internal Medicine, 64, 378.

Carriza, J., Levison, M. E., Lawrence, T., and Kaye, D. (1974). Cure of Aspergillus ustus endocarditis on a prosthetic valve. Archives of Internal Medicine, 133, 486.

Chaudhuri, M. R. (1970). Fungal endccarditis after valve replacements. Journal of Thoracic and Cardiovascular Surgery, 60, 207.

Clinico-pathological conference (1969). A case of fungal endocarditis. British Medical Journal, 3, 765.

Conway, N., Kothari, M. L., Lockey, E., and Yacoub, M. H. (1968). Candida endocarditis after heart surgery. Thorax, 23, 353.

Dismukes, W. E., Karchmer, A. W., Buckley, M. J., Austen, W. G., and Swartz, M. N. (1973). Prosthetic valve endocarditis: an analysis of 38 cases. Circulation, 48, 365.

Engelman, R. M., Chase, R. M. Jr., Boyd, A. D., and Reed, G. E. (1973). Lethal postoperative infections following cardiac surgery. Circulation, 47 and 48, Supplement 3, 31.

Gage, A. A., Dean, D. C., Schimert, G., and Minsley, N. (1974). Aspergillus infection after cardiac surgery. Archives of Surgery, 101, 384.

Hairston, P. and Lee, W. H. Jr. (1970). Management of infected prosthetic heart valves. Annals o $\overrightarrow{\mathrm{E}}$ Thoracic Surgery, 9, 229.

Harford, C. G. (1974). Postoperative fungal endc음 carditis. Archives of Internal Medicine, 134, 116은

Hiddleston, H. J. H., Rosser, T. H. L., and Seal $\frac{\bar{T}}{2}$ R. M. E. (1954). Pulmonary aspergillosis 0 Tubercle, 35, 15.

Kammer, R. B. and Utz, J. P. (1974). A spergillus species endocarditis. American Journal o $\bar{\zeta}$ Medicine, 56, 506.

Lee, W. H. Jr., Krumhaar, D., Fonkalsrud, E. W. $\vec{\omega}$ Schjeide, O. A., and Maloney, J. V. Jr. (1961) Denaturation of plasma proteins as a cause of morbidity and death after intracardiac opera tions. Surgery, 50, 29.

Mullins, J. (1974). The ecology of Aspergillus fumi gatus. PhD thesis, University of Wales.

Mullins, J. (1975). Personal communication.

Murray, I. G., Buckley, H. R., and Turner, G. C. (1969). Serological evidence of Candida infection after open-heart surgery. Journal of Medicat Microbiology, 2, 463.

Newman, W. H. and Cordell, A. R. (1964). Asper gillus endocarditis after open-heart surgery $\vec{c}$ Journal of Thoracic and Cardiovascular Surgery
48, 652 .

Public Health Laboratory Service (1970). Mycoses: British Medical Journal, 2, 185.

Shafer, R. B. and Hall, W. H. (1970). Bacterial endoō carditis following open-heart surgery. America倦 Journal of Cardiology, 25, 602.

Werner, A. S., Cobbs, C. G., Kaye, D., and Hcok E. W. (1967). Studies on the bacteremia of bacterial endocarditis. Journal of the Americat Medical Association, 202, 199.

Yeh, T. J., Anabtawi, I. N., Cornett, V. E., White, A Stern, W. H.. and Ellison, R. G. (1967). Bacteriat+ endocarditis following open-heart surgery. Annalo of Thoracic Surgery, 3, 29.

Requests for reprints to: Dr. I. S. Petheram, Sull: Hospital, Sully, Penarth, Glamorgan CF6 2YA. 